DOI: $10.29303 /$ jrpb.v9i1.245

ISSN 2301-8119, e-ISSN 2443-1354

Tersedia online di http://jrpb.unram.ac.id/

\title{
PRA-PERLAKUAN BLANSING PADA PENGERINGAN TIPE BEKU (FREEZE DRYING) UNTUK MEMPERTAHANKAN KUALITAS PETAI (Parkia speciosa)
}

\author{
Blanching Pretreatment on Freeze-drying Process to Preserve the Quality of Parkia speciosa
}

\section{Joko Nugroho Wahyu Karyadi*), Muhammad Adani Akbar, Dwi Ayuni, Nursigit Bintoro}

Departemen Teknik Pertanian dan Biosistem, Fakultas Teknologi Pertanian, Universitas Gadjah Mada

Jl. Flora, Bulaksumur, Yogyakarta 55281, Indonesia

Email ${ }^{*}$ : jknugroho@ugm.ac.id

Diterima: Desember 2020

Disetujui: Maret 2021

\begin{abstract}
Petai (Parkia speciosa), or known as bitter-bean, is a type of food that has unique taste and rich nutrition content. These properties make petai have the potential to be processed into an exotic vegetable targeting national and international markets. However, like other vegetables, the quality of petai is greatly influenced by environmental conditions. One solution for petai storage is the drying process. This study aims to determine the effect of blanching pre-treatment on the physical quality of freeze-dried petai. Two variations of blanching, namely blanching with hot water (HWB) and blanching with hot steam (SB), are carried out before the drying process. Besides, cabinet drying is also used as another variation to know about the difference of freeze-drying from other methods. The quality measured in this study included drying characteristics, moisture content, weight loss, shrinkage ratio, material hardness, color, and chlorophyll content. The freeze dryer used in this study is a self-designed dryer with total dimensions of $0.5 \times 0.7 \times 1.0 \mathrm{~m}$. The results showed that the drying characteristics of petai drying were best described by the first-order kinetics model (R2> 0.95; RMSE <0.1). The lowest final moisture content obtained from freezedrying, with values ranged from 2 - 3\% w.b. Freeze drying reduces the risk of discoloration in petai better compared to cabinet drying. Blanching pre-treatment was proven to increase the drying rate and to preserve chlorophyll content in petai.
\end{abstract}

Keywords: drying kinetics; physical quality; freeze-drying; parkia speciose; blanching pretreatment;

\begin{abstract}
ABSTRAK
Petai (Parkia speciosa) merupakan salah satu jenis makanan yang memiliki ciri khas rasa yang unik serta nutrisi yang melimpah. Karakteristik tersebut membuat petai berpotensi untuk diolah menjadi sayuran eksotis dengan sasaran pasar nasional maupun internasional. Meskipun begitu, seperti halnya sayuran lain, kualitas petai sangat dipengaruhi oleh kondisi lingkungan. Salah satu solusi untuk penyimpanan petai adalah dengan proses pengeringan. Penelitian ini bertujuan untuk mengetahui pengaruh pra-perlakuan blansing terhadap kualitas fisik petai hasil pengeringan tipe beku (freeze-drying). Dua variasi jenis blansing, yaitu blansing dengan air panas (HWB) dan blansing dengan uap panas (SB) dilakukan sebelum proses pengeringan. Selain itu, pengeringan tipe cabinet juga dilakukan sebagai pembandingan. Kualitas yang diukur pada penelitian ini
\end{abstract}


meliputi karakteristik pengeringan, kadar air, susut bobot, shrinkage ratio, kekerasan bahan, warna, dan kandungan klorofil. Pengering beku yang digunakan pada penelitian ini ialah pengering hasil rancangan sendiri yang berdimensi total 0,5 x 0,7 x 1,0 m. Hasil penelitian menunjukkan bahwa karakteristik penurunan kadar air pada proses pengeringan beku untuk petai secara baik dideskripsikan dengan model kinetika orde satu $\left(\mathrm{R}^{2}>0,95 ; \mathrm{RMSE}<0,1\right)$. Kadar air akhir terendah didapatkan dari pengeringan beku, dengan rentang kadar air $2-3 \%$ w.b. Pengeringan beku dapat mengurangi resiko discoloration pada petai, dibandingkan dengan pengering tipe cabinet. Praperlakuan blansing terbukti dapat membantu meningkatkan laju pengeringan sehingga pengeringan berlangsung lebih cepat, dan kandungan klorofil didalam petai dapat terjaga lebih baik.

Kata kunci: kinetika pengeringan; kualitas fisik; pengering beku; petai; pra-perlakuan blansing

\section{PENDAHULUAN}

\section{Latar Belakang}

Petai (Parkia speciosa) merupakan salah satu sayuran dari jenis polongpolongan yang banyak di jumpai di negaranegara Asia Tenggara. Di Indonesia, petai menjadi salah satu tanaman sayuran tahunan (Annual vegetable plants) dengan produksi terbesar. Menurut Badan Pusat statistik Indonesia, kenaikan produksi tanaman petai di tahun 2018 adalah yang tertinggi, sebesar $43,72 \%$, diikuti tanaman jengkol dan melinjo (Badan Pusat Statistik, 2018).

Petai menjadi sayuran yang digemari untuk dikonsumsi dalam keadaan segar, maupun direbus terlebih dahulu. Penelitian terdahulu menjelaskan lebih lanjut tentang khasiat dari petai, dan menunjukkan bahwa petai kaya akan nutrisi seperti protein, lemak, karbohidrat, kalsium, dan zat besi (Chhikara, et al., 2018). Petai juga memiliki kandungan antioksidan yang tinggi, khususnya fenol, sehingga berpotensi untuk dijadikan obat herbal dan mampu mengobati penyakit seperti hipertensi, diabetes, dll. (Silva, et al., 2016).

Kombinasi rasa yang unik serta originalitas khas negara tropis, menjadikan petai sebagai komoditas unggulan ekspor beberapa provinsi di Indonesia seperti Riau dan Banten (Hayati \& Yanuwardhana, 2019; Putri \& Zuraya, 2019; Rima, 2018). Meskipun begitu, seperti halnya sayuran lain, sulit untuk menjaga kualitas petai untuk dapat disimpan dalam waktu yang lama. Hal ini tentu menjadi tantangan usaha ekspor petai.

Salah satu teknik untuk menjaga kualitas petai adalah dengan metode pengeringan beku (freeze-drying). Beberapa sayuran telah berhasil dikeringkan dengan metode pengeringan beku, antara lain seledri dan bawang prei (Eisinaite, et al., 2016), serta edamame (Kamila, et al., 2019), dan lain-lain. Sayuran yang sebelum disimpan melalui proses pengeringan beku tidak akan mengalami perubahan bentuk, warna, maupun rasa (Sagar, et al., 2018).

Pada penelitian sebelumnya telah dilakukan pengeringan beku petai dengan alat pengering beku yang dirancang secara mandiri. Dari penelitian tersebut, didapatkan bahwa pengering dapat berfungsi dengan baik, dan dapat mengeringkan petai selama 36 jam, dengan kadar air mencapai 9,87\% (Akbar, et al., 2019). Pada penelitian kali ini laju pengeringan petai akan ditingkatkan dengan pra-perlakuan blansing pada bahan sebelum proses pengeringan.

Pada proses blansing (blanching), sayuran mengalami kontak dengan suhu panas dalam waktu yang singkat, proses blansing dapat melunakkan matriks dari bahan, sehingga memudahkan air yang ada di dalam bahan untuk bergerak dan menguap, sehingga laju pengeringan menjadi meningkat (Peters \& Ramirez, 2019). Selain itu, panas yang diberikan juga dapat menghambat penyebaran kuman dan bakteri di dalam sayuran tersebut. Dengan demikian, kualitas sayur diharapkan dapat 
bertahan untuk waktu penyimpanan yang lebih lama (Nollet, 2010).

\section{Tujuan}

Tujuan dari penelitian ini adalah untuk mengetahui pengaruh pra-perlakuan blansing terhadap kinetika pengeringan dan untuk mempertahankan kualitas petai hasil pengeringan beku (freeze-drying).

\section{METODE PENELITIAN}

\section{Persiapan Bahan}

Bahan baku yang digunakan pada penelitian ini adalah biji petai yang segar dan matang secara fisiologis, dicirikan dengan biji yang keras serta warna biji hijau tua. Satu produsen utama petai dipilih, dengan tujuan agar varietas dan kualitas awal dari petai yang dipakai pada penelitian ini seragam. Petai mulai diberi perlakukan 4 - 6 hari setelah panen. Biji petai yang akan digunakan dikupas dari buahnya dan dibersihkan dari kulit ari. Berat biji petai yang digunakan berkisar antara $3-6$ gram.

Pada penelitian ini, petai yang telah dikupas dan dibersihkan kemudian dibedakan menjadi tiga kelompok, yaitu kelompok tanpa perlakuan (kontrol), blansing menggunakan air panas (hot water blanching method, HWB) dan blansing dengan menggunakan uap panas (steam blanching method, SB). Pada metode HWB, petai dicelupkan ke dalam air panas $\left(90^{\circ} \mathrm{C}\right)$ menggunakan water bath (ADVANTEC TX272DA, Dublin, CA). Sementara itu pada metode SB, petai diletakkan ke dalam panci pengukus yang sebelumnya berisi $2 \mathrm{~L}$ air. Uap pengukusan yang digunakan ialah sekitar $100^{\circ} \mathrm{C}$. Setiap proses blansing berlangsung selama 30 detik.

\section{Pengering tipe Cabinet (Cabinet Dryer)}

Pengeringan tipe cabinet (CD) juga dilakukan sebagai parameter pembanding produk petai kering yang dihasilkan. Petai yang telah dibersihkan dimasukkan ke dalam cabinet dryer (PSN-150, Shimizu Scientific Instruments MFG. CO., LTD.,
Tokyo, Japan). Pengeringan diatur pada suhu $60^{\circ} \mathrm{C}$ selama 12 jam.

\section{Pengering Beku (Freeze Dryer)}

Proses pengeringan beku (FD) yang dilakukan pada penelitian ini, menggunakan alat pengering skala laboratorium yang dikonstruksi secara mandiri (Gambar 1). Pengering dibuat dengan dimensi total $0,5 \mathrm{x}$ $0,7 \times 1,0 \mathrm{~m}$. Di dalamnya, terdapat ruang pengering yang memiliki dimensi diameter $0,4 \mathrm{~m}$ dan panjang $0,6 \mathrm{~m}$. Pengering dibuat menggunakan baja tahan karat dengan ketebalan $3 \mathrm{~mm}$, dan terdiri dari pompa vakum, pintu, kompresor $1 / 4 \mathrm{HP}$, refrigerant $\mathrm{R} 134 \mathrm{~A}$, dan cold trap. Sistem pemanas menggunakan empat buah plat pemanas segi empat $(0,2 \times 0,4) \mathrm{m}^{2}$, yang berdaya 2.000 watt. Plat pemanas dipasang pada bagian atas dan bawah setiap nampan rak pengering.

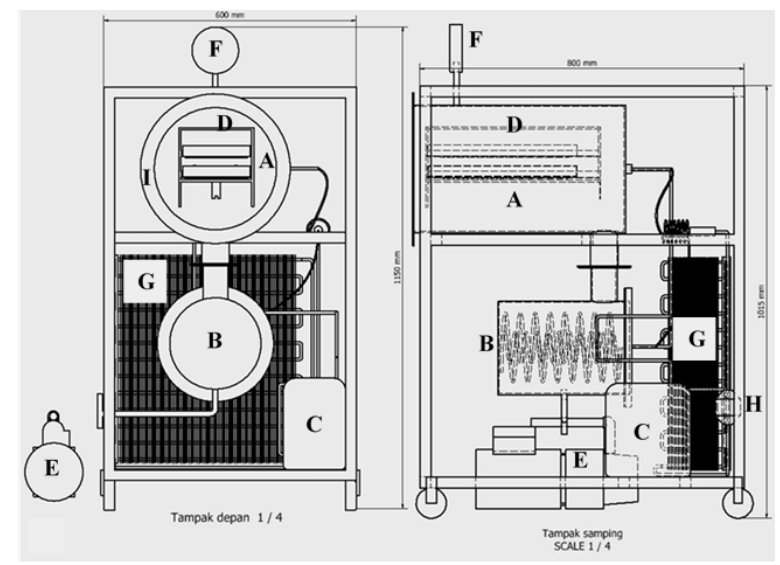

Gambar 1. Skema Freeze Dryer

Keterangan: (A) Ruang Pengering, (B)

Coldtrap, (C) Kompresor, (D) Heater, (E)

Pompa Vakum, (F) Thermostat, (G)

Kondensor, (H) Filter dryer, (I) Evaporator, (J) Kran Pembuangan

Petai yang telah melalui proses blansing diletakkan secara merata di atas nampan rak pengering. Terdapat dua rak di dalam pengering beku, di mana satu rak pengering diisi kurang lebih 45 biji petai. Kemudian, proses pengeringan diawali dengan pembekuan hingga $-18^{\circ} \mathrm{C}$ selama 6 jam dalam kondisi vakum. Selanjutnya ialah proses pengeringan primer dan sekunder, yang terjadi selama 30 jam, dengan suhu 
pelat pemanas dikontrol pada $60^{\circ} \mathrm{C}$. Setelah proses pengeringan selesai, produk ditimbang untuk selanjutnya diamati karakteristik fisik dan nutrisinya.

\section{Kadar Air}

Kadar air bahan diukur dengan menggunakan metode pengeringan dengan oven, mengikuti kaidah AOAC (Nag \& Dash, 2016). 5 g sampel dikeringkan dengan oven (Memmert UM-400, Memmert GmbH + Co.KG, Schwabach, Germany) pada suhu $105^{\circ} \mathrm{C}$ selama 24 jam. Perbedaan massa sebelum dan setelah pengeringan dengan oven dianggap sebagai jumlah air yang terkandung di dalam bahan, yang kemudian dihitung dengan rumus berikut:

$$
M=\frac{W_{0}-W_{1}}{W_{0}} \times 100 \%
$$

Dimana:

$M=$ kadar air bahan $(\% \mathrm{wb})$

$W_{0}=$ massa bahan sebelum pengeringan dengan oven $(\mathrm{g})$

$W_{l}=$ massa bahan setelah pengeringan dengan oven ( $\mathrm{g}$ )

Selanjutnya untuk melakukan

perbandingan karakteristik pengeringan antar variasi, dilakukan perhitungan Moisture ratio (MR). Karena (equilibrium moisture content) $M_{e}$ sangatlah rendah dan dapat diabaikan, maka MR disederhanakan menjadi persaman di bawah ini (Liu, et al., 2016):

$M R=\frac{M-M_{e}}{M_{0}-M_{e}} \approx \frac{M}{M_{0}}$

MR kemudian dideskripsikan dengan model kinetika orde, yaitu kinetika orde nol:

$M R=M R_{0}-k t$

Serta kinetika orde 1 (Orikasa, et al., 2018): $M R=e^{-k t}$

Dimana:

$$
\begin{array}{ll}
M R & =\text { moisture ratio }(-) \\
M R_{0} & =\text { MR saat awal pengeringan }(-) \\
k & =\text { konstanta laju pengeringan }\left(\mathrm{h}^{-1}\right) \\
t & =\text { waktu pengeringan }(\mathrm{jam})
\end{array}
$$

Konstanta pengeringan, $k$, diperkirakan dengan menyesuaikan data MR yang diperoleh pada persamaan 3 atau 4 menggunakan metode kuadrat terkecil (least-squares method). Untuk evaluasi goodness of fit dilakukan perhitungan koefisien determinasi $\left(\mathrm{R}^{2}\right)$ dan RMSE (Saberian, et al., 2014):

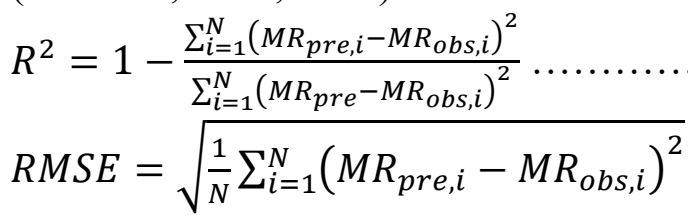

Dimana:

$N \quad=$ jumlah pengamatan

$M R_{\text {pre }, i}=\mathrm{MR}$ prediksi ke $-i$

$M R_{o b s, i}=$ MR observasi ke $-i$

\section{Susut Bobot}

Susut bobot merupakan persentasi perbedaan massa awal bahan dan massa akhir bahan setelah pengeringan. Selain kadar air bahan hasil pengeringan, susut bobot juga penting untuk diketahui untuk mengevaluasi efisiensi pengeringan yang dilakukan. Susut bobot dihitung berdasarkan rumus berikut (Liu, et al., 2019):

$W L=\frac{W_{0}-W_{d}}{W_{0}} \times 100 \%$

Dimana:

$W L=$ Susut bobot $(\%)$

$W_{0}=$ massa bahan sebelum pengeringan beku ( $\mathrm{g})$

$W_{d}=$ massa bahan setelah pengeringan beku (g)

\section{Shrinkage Ratio}

Penelitian-penelitian sebelumnya menyebutkan bahwa salah satu keunggulan penggunaan blansing sebagai pra-perlakuan pengeringan adalah meningkatnya nilai shrinkage ratio. Dalam penelitian ini, penentuan volume petai sebelum dan sesudah pengeringan dihitung dengan rumus geometric mean diameter $\left(D_{g}\right)$, sebagai berikut (Taner, et al., 2018):

$D_{g}=(L \times W \times T)^{1 / 3}$

$V=\frac{\pi \times L \times W \times T}{6}$

Dimana:

$V=$ volume bahan $\left(\mathrm{m}^{3}\right)$

$L \quad=$ panjang $(\mathrm{m})$

$W=$ lebar $(\mathrm{m})$ 
$T \quad=$ tebal $(\mathrm{m})$

Selanjutnya, shrinkage ratio dihitung dengan membandingkan volume petai sebelum dan sesudah pengeringan, yang dihitung dengan rumus berikut (Wang, et al., 2018):

$S R=\frac{V_{d}}{V_{0}}$

Dimana:

$S R=$ shrinkage ratio $(-)$

$V_{d}=$ Volume bahan setelah pengeringan $\left(\mathrm{m}^{3}\right)$

$V_{0}=$ Volume bahan sebelum pengeringan $\left(\mathrm{m}^{3}\right)$

\section{Tekstur bahan}

Tekstur merupakan salah satu faktor penentu kualitas dari produk bahan pangan. Khususnya pada hasil pengeringan beku, bahan diharapkan memiliki tekstur yang renyah, karena sifat hasil pengering beku dimana kadar air teruapkan secara sempurna namun matriks Analisis tekstur bahan sebelum dan sesudah pengeringan dilakukan dengan mengukur tingkat kekerasan (hardness) dari bahan menggunakan Texture Analyser (Brookfield CT3 Texture Analyser, Middleboro, MA, USA).

Pada pengukuran ini digunakan probe berbentuk silinder tipe TA39 $($ diameter $=2$ $\mathrm{mm}$ ), dengan laju tekanan diatur $1 \mathrm{~mm} / \mathrm{s}$. Pertama-tama, bahan diletakkan di atas meja sampel pada alat yang telah diatur kondisi analisisnya. Bahan dipastikan memiliki permukaan yang rata dan tidak mudah bergerak. Kemudian alat akan dijalankan, dan bahan akan di tekan sampai probe menembus bahan sedalam setengah dari tebal bahan. Kekerasan bahan dikuantifikasi sebagai puncak compression force, dan diukur dengan satuan $g_{f}$ (gram force).

\section{Warna}

Warna merupakan salah satu parameter penentu kualitas fisik dari produk pertanian. Pada penelitian ini perubahan masing-masing komponen warna lightness $\left(L^{*}\right)$, redness $\left(a^{*}\right)$, and yellowness $\left(b^{*}\right)$ diukur menggunakan color meter Color
Meter (Color Meter TES-135A, TES Electrical Electronic Corp., Taipei, Taiwan).

\section{Kandungan Klorofil}

Pengukuran klorofil dilakukan dengan menggunakan metode yang diadopsi dari ARNON (Esteban, et al., 2018), menggunakan alat spektrofotometer (Thermo Scientific Genesys 20, Thermo Fisher Scientific, MA, USA). Data dihitung pada basis kering, dan dilaporkan dengan satuan $\mathrm{mg} / \mathrm{g}$ padatan.

\section{Scanning electron microscopy}

Morfologi permukaan petai segar maupun yang telah dikeringkan diamati dengan menggunakan Scanning electron microscopy (SEM; JSM 6510LA JEOL Ltd., Tokyo, Japan). Pt-Pd digunakan sebagai coater, dan pengamatan dilakukan dengan perbesaran $1000 \mathrm{X}$ dan $5000 \mathrm{X}$.

\section{Analisis Statistik}

Analisis variansi (ANOVA) dilakukan menggunakan software program IBM SPSS Statistics 23 software (SPSS Inc., Chicago, IL). Tes untuk mengetahui perbedaan signifikan antar nilai rerata karakteristik fisik petai kering ditentukan dengan Duncan Multiple Range Test (DMRT) dengan tingkat kepercayaan 95\% $(p<0.05)$.

\section{HASIL DAN PEMBAHASAN}

\section{Karakteristik Pengeringan Beku}

Tabel 1 menunjukkan analisis regresi model kinetika orde nol dan orde 1 untuk masing-masing variasi pengeringan. Model yang baik umumnya menunjukkan nilai $\mathrm{R}^{2}$ tertinggi dan nilai RMSE terendah (Nkwocha, et al., 2018). Berdasarkan pernyataan tersebut, maka penurunan moisture ratio pada pengeringan beku untuk petai paling baik dideskripsikan dengan kinetika orde 1. Hal ini ditandai dengan nilai $\mathrm{R}^{2}$ yang paling mendekati 1 , serta RMSE yang rendah, berada pada rentang 0,05 0,07 . 
Tabel 1. Hasil analisis regresi model kinetika untuk variasi pengeringan beku petai

\begin{tabular}{clcc}
\hline $\begin{array}{c}\text { Kinetika } \\
\text { order }(\mathrm{n})\end{array}$ & Perlakuan ${ }^{*}$ & $\mathrm{R}^{2}$ & $\mathrm{RMSE}$ \\
\hline 0 & FD & 0,974 & 0,061 \\
0 & FD-HWB & 0,897 & 0,121 \\
0 & FD-SB & 0,906 & 0,110 \\
\hline 1 & FD & 0,969 & 0,063 \\
1 & FD-HWB & 0,971 & 0,058 \\
1 & FD-SB & 0,951 & 0,075 \\
\hline
\end{tabular}

*FD = Perlakuan pengeringan beku; FD-HWB = Pengeringan beku dengan pra-perlakuan hot water blanching; FD-SB = Pengeringan beku dengan praperlakuan steam blanching

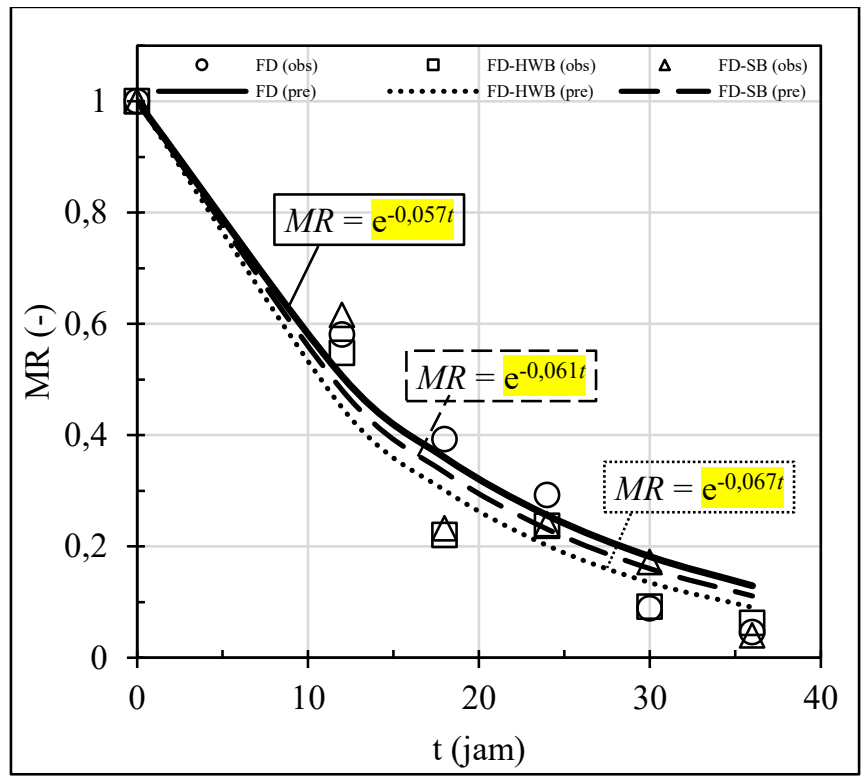

Gambar 2. Kinetika orde 1 untuk penurunan nilai MR selama pengeringan petai dengan metode pengeringan beku

Gambar 2 menunjukkan grafik kinetika orde 1 untuk pengeringan beku petai. Dari kinetika orde 1 selanjutnya ditentukan nilai konstanta laju pengeringan untuk masing-masing variasi. Nilai konstanta $(k)$ tersebut ialah 0,$057 ; 0,067$; dan $0,061 \mathrm{~h}^{-1}$ untuk masing-masing variasi FD, FD-HWB, dan FD-SB. Dari hasil dapat dilihat bahwa pemberian pra-perlakuan blansing telah menaikkan nilai konstanta laju pengeringan hingga $17 \%$. Hal ini dapat diartikan bahwa proses blansing mampu meningkatkan laju pengeringan, sehingga proses dehidrasi berlangsung lebih cepat. Penemuan ini sejalan dengan pendapat sebelumnya, yang mengatakan bahwa proses blansing mencegah pengerasan pada permukaan bahan, di mana pengerasan tersebut dapat menghambat pergerakan air di dalam bahan menuju permukaan (Bills \& Bills, 2010; Peters \& Ramirez, 2019). Orikasa, et al. (2018) mengeringkan paprika menggunakan far-infrared drying, mengungkapkan bahwa perlakuan blansing meningkatkan laju pengeringan paprika 1,6 kali lebih cepat dibandingkan dengan yang tanpa perlakuan blansing.

\section{Kualitas Fisik}

Tabel 2 menunjukkan kualitas fisik produk hasil pengeringan tipe cabinet dan pengeringan beku. Rerata kadar air petai segar ialah 28,96 $\pm 0,34 \%$ w.b. Dari hasil DMRT, diketahui bahwa petai yang dikeringkan dengan variasi pengeringan beku memiliki kadar air akhir yang lebih rendah secara signifikan bila dibandingkan dengan hasil variasi pengeringan tipe cabinet $(\mathrm{p}<0,05)$, yaitu berkisar antara $2-$ $3 \%$ w.b. Kadar air merupakan salah satu faktor penentu umur simpan produk makanan, karena produk dengan kadar air yang rendah dapat dinyatakan stabil secara mikrobiologi, dan dapat disimpan secara aman untuk waktu yang lama (Guiné, 2018). Berdasarkan pernyataan tersebut, maka dapat dikatakan bahwa pengeringan beku efektif untuk mengeringkan petai hingga kadar air rendah, agar aman untuk disimpan dalam waktu yang lama.

Nilai kadar air yang didapatkan sejalan dengan nilai susut bobot, dimana susut bobot hasil pengeringan beku lebih besar hingga $20 \%$ jika dibandingkan dengan hasil pengeringan tipe cabinet. Biji petai segar memiliki nilai kekerasan 256,11 \pm 57,62 gf. Setelah proses pengeringan, nilai kekerasan biji petai meningkat lebih dari 2 kali lipat. Meskipun begitu, perlakuan blansing tidak memberikan perbedaan yang signifikan terhadap nilai shrinkage ratio dan nilai kekerasan petai kering $(\mathrm{p}>0,05)$.

\section{Perubahan Warna}

Tabel 3 menunjukkan perubahan komponen warna pada petai sebelum dan 
sesudah pengeringan. Hasil DMRT menunjukkan adanya penurunan nilai lightness yang signifikan antara petai sebelum dan sesudah proses pengeringan ( $p$ $<0,05$ ). Penurunan nilai lightness berkisar antara $10-30$, dengan masing-masing nilai berbeda untuk setiap perlakuan. Penurunan ini diduga terjadi karena proses pengeringan yang mengandalkan panas, menyebabkan terjadinya proses kehilangan warna (heat discoloration) dan nutrisi pada produk yang dihasilkan (Kudra \& Mujumdar, 2015; Mühlbauer \& Müller, 2020).

Meskipun begitu, terdapat kecenderungan yang signifikan pada hasil pengukuran komponen warna $a^{*}$ dan $\Delta E$. Nilai minus pada komponen $a^{*}$ menunjukkan koordinat warna hijau dari biji petai (Bora, et al., 2015). $-a^{*}$ dari petai kering hasil pengeringan beku secara siknifikan lebih besar dari petai kering hasil pengeringan tipe cabinet $(\mathrm{p}<0,05)$. Hasil ini sejalan dengan nilai $\Delta E$, dimana nilai $\Delta E$ pengeringan beku secara signifikan lebih kecil $(\mathrm{p}<0,05)$. Hasil ini mengindikasikan bahwa walaupun pengeringan beku juga menyebabkan discoloration pada petai kering yang dihasilkan, namun masih dapat menekan perubahan warna biji petai lebih baik jika dibandingkan dengan pengeringan tipe cabinet.. Kesimpulan serupa juga dihasilkan oleh pengeringan beku untuk bubuk labu kuning (Roongruangsri \& Bronllund, 2016). Sementara itu, dari hasil DMRT didapatkan tidak ada pengaruh signifikan dari pemberian perlakuan blansing terhadap nilai komponen warna $(\mathrm{p}>0,05)$.

Tabel 2. Analisis kualitas fisik petai hasil pengeringan

\begin{tabular}{lcccc}
\hline Perlakuan $^{*}$ & $\begin{array}{c}\text { Kadar air } \\
(\% \text { w.b. })\end{array}$ & $\begin{array}{c}\text { Susut bobot } \\
(\%)\end{array}$ & $\begin{array}{c}\text { Shrinkage } \\
\text { ratio }(-)\end{array}$ & $\begin{array}{c}\text { Kekerasan } \\
\text { bahan }(\mathrm{gf})\end{array}$ \\
\hline CD & $7,08 \pm 0,64^{\mathrm{d}}$ & $51,52 \pm 5,28^{\mathrm{a}}$ & $0,38 \pm 0,06^{\mathrm{a}}$ & $1752,67 \pm 650,33^{\mathrm{abc}}$ \\
CD-HWB & $4,62 \pm 0,94^{\mathrm{c}}$ & $53,47 \pm 3,14^{\mathrm{a}}$ & $0,36 \pm 0,08^{\mathrm{a}}$ & $2406,67 \pm 500,07^{\mathrm{c}}$ \\
CD-SB & $4,26 \pm 1,97^{\mathrm{bc}}$ & $55,05 \pm 8,84^{\mathrm{a}}$ & $0,38 \pm 0,07^{\mathrm{a}}$ & $1571,00 \pm 98,09^{\mathrm{ab}}$ \\
FD & $2,22 \pm 0,74^{\mathrm{a}}$ & $64,29 \pm 0,75^{\mathrm{b}}$ & $0,36 \pm 0,09^{\mathrm{a}}$ & $1355,44 \pm 33,49^{\mathrm{a}}$ \\
FD-HWB & $2,74 \pm 0,86^{\mathrm{ab}}$ & $71,58 \pm 0,23^{\mathrm{b}}$ & $0,31 \pm 0,09^{\mathrm{a}}$ & $2308,00 \pm 774,91^{\mathrm{bc}}$ \\
FD-SB & $2,42 \pm 0,32^{\mathrm{a}}$ & $68,53 \pm 0,34^{\mathrm{b}}$ & $0,36 \pm 0,02^{\mathrm{a}}$ & $1882,44 \pm 113,14^{\mathrm{abc}}$ \\
\hline
\end{tabular}

Nilai rerata $(\mathrm{n}=3)$ dengan huruf kecil superscript pada kolom yang sama mengindikasikan perbedaan signifikan antar sampel $(\mathrm{P}<0.05)$

*FD $=$ Perlakuan pengeringan beku; $\mathrm{CD}=$ Perlakuan pengeringan dengan cabinet dryer; $\mathrm{HWB}=$ Pengeringan dengan pra-perlakuan hot water blanching; $\mathrm{SB}=$ Pengeringan dengan pra-perlakuan steam blanching

Tabel 3. Hasil pengukuran komponen warna petai sebelum dan sesudah pengeringan

\begin{tabular}{lcccc}
\hline \multirow{2}{*}{ Perlakuan* } & \multicolumn{4}{c}{ Nilai komponen warna } \\
\cline { 2 - 5 } & $L^{*}$ & $a^{*}$ & $b^{*}$ & $\Delta E$ \\
\hline Segar & $78,04 \pm 7,38^{\mathrm{d}}$ & $-40,07 \pm 8,42^{\mathrm{a}}$ & $69,81 \pm 8,23^{\mathrm{e}}$ & - \\
CD & $54,11 \pm 4,65^{\mathrm{ab}}$ & $-5,50 \pm 0,64^{\mathrm{de}}$ & $22,30 \pm 5,83^{\mathrm{a}}$ & $63,78 \pm 17,64^{\mathrm{cd}}$ \\
CD-HWB & $46,83 \pm 1,38^{\mathrm{a}}$ & $-1,95 \pm 1,12^{\mathrm{e}}$ & $13,51 \pm 3,51^{\mathrm{a}}$ & $75,07 \pm 13,05^{\mathrm{d}}$ \\
CD-SB & $58,06 \pm 8,15^{\mathrm{bc}}$ & $-8,03 \pm 0,15^{\mathrm{cd}}$ & $21,67 \pm 3,46^{\mathrm{a}}$ & $61,69 \pm 11,08^{\mathrm{d}}$ \\
FD & $64,46 \pm 2,56^{\mathrm{c}}$ & $-25,83 \pm 0,47^{\mathrm{b}}$ & $60,03 \pm 4,65^{\mathrm{d}}$ & $22,17 \pm 10,84^{\mathrm{a}}$ \\
FD-HWB & $53,04 \pm 4,36^{\mathrm{ab}}$ & $-21,17 \pm 1,32^{\mathrm{b}}$ & $49,34 \pm 3,57^{\mathrm{c}}$ & $37,72 \pm 7,93^{\mathrm{ab}}$ \\
FD-SB & $50,00 \pm 1,50^{\mathrm{ab}}$ & $-12,19 \pm 0,71^{\mathrm{c}}$ & $37,85 \pm 3,77^{\mathrm{b}}$ & $50,97 \pm 11,17^{\mathrm{bc}}$ \\
\hline
\end{tabular}

Nilai rerata $(\mathrm{n}=3)$ dengan huruf kecil superscript pada kolom yang sama mengindikasikan perbedaan signifikan antar sampel $(\mathrm{P}<0.05)$

$* \mathrm{FD}=$ Perlakuan pengeringan beku; $\mathrm{CD}=$ Perlakuan pengeringan dengan cabinet dryer; $\mathrm{HWB}=$ Pengeringan dengan pra-perlakuan hot water blanching; $\mathrm{SB}=$ Pengeringan dengan pra-perlakuan steam blanching 


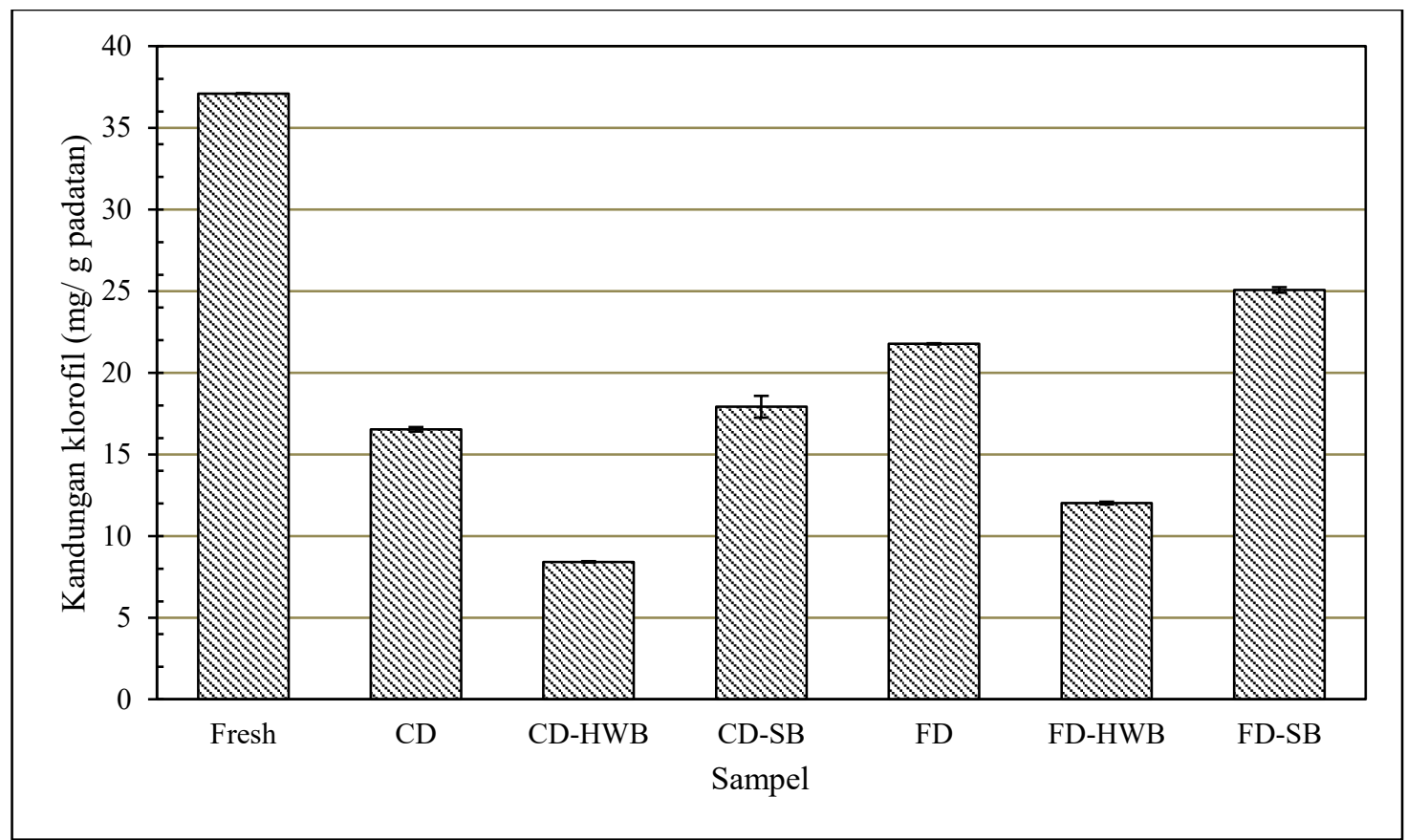

Gambar 3. Grafik kandungan klorofil pada petai sebelum dan sesudah pengeringan Keterangan sampel: $\mathrm{FD}=$ Perlakuan pengeringan beku; $\mathrm{CD}=$ Perlakuan pengeringan dengan cabinet dryer; $\mathrm{HWB}=$ Pengeringan dengan pra-perlakuan hot water blanching; $\mathrm{SB}=$ Pengeringan dengan pra-perlakuan steam blanching
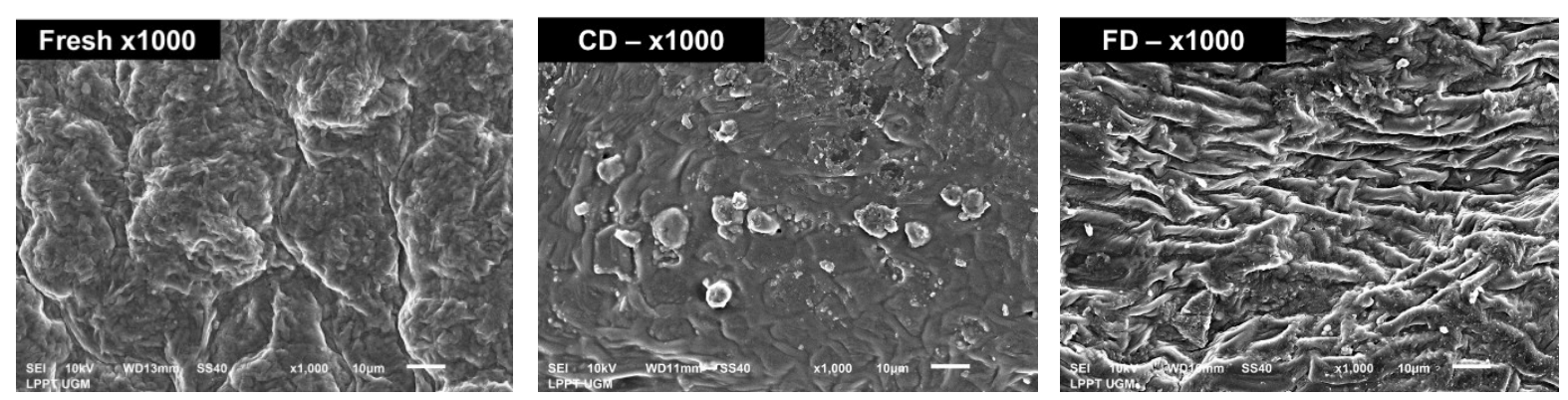

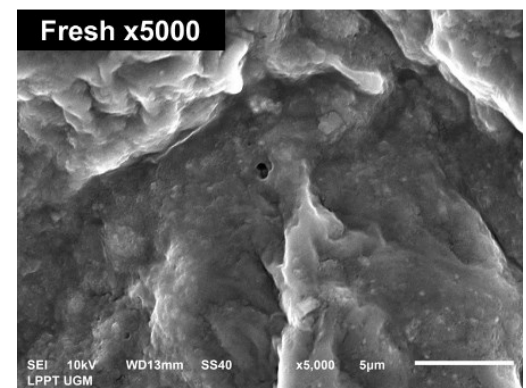

(a)



(b)

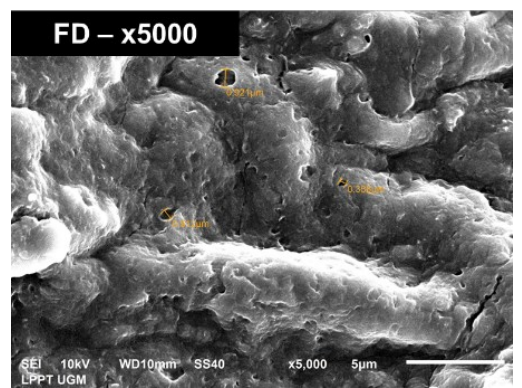

(c)

Gambar 4. Hasil pengamatan mikrostruktur menggunakan scanning electron microscopy untuk perlakuan petai segar (a); petai hasil pengeringan tipe cabinet (b); dan petai hasil pengeringan beku (c) 


\section{Kandungan Klorofil}

Sayuran hijau yang dikeringkan sebelum proses penyimpanan dapat memelihara nilai klorofil pada produk. Karena nilai klorofil sangat rentan terhadap faktor seperti oksigen, panas, dan cahaya, maka penentuan nilai klorofil sebelum dan sesudah pengeringan menjadi faktor penentu keberhasilan proses pengeringan tersebut. Gambar 3 menunjukkan grafik nilai klorofil masing-masing variasi perlakuan sebelum dan sesudah pengeringan. Dapat dilihat pada grafik, bahwa nilai klorofil pada petai turun secara drastis setelah proses pengeringan, baik pengering tipe cabinet maupun pengering tipe beku. Pra-perlakuan blansing dengan uap (SB) terbukti dapat menjaga klorofil lebih baik daripada HWB, pada kedua jenis pengeringan. Peran blansing untuk menjaga nilai klorofil juga dikonfirmasi pada penelitian sebelumnya untuk bahan jeruk nipis (Kaewsuksaeng, et al., 2015).

\section{Scanning electron microscopy}

Gambar 4 menunjukkan hasil pengamatan morfologi permukaan petai saat kondisi segar (a), sesudah pengeringan tipe cabinet (b), dan sesudah pengeringan tipe beku (c). Mikrografis ditunjukkan dengan dua variasi perbesaran, yaitu perbesaran x1000 dan perbesaran x5000. Dari gambar dapat dilihat bahwa hasil pengeringan FD menunjukkan struktur yang solid dan kaku. Pada perbesaran x 5000, terlihat lebih jelas bahwa hasil pengeringan $C D$ memiliki permukaan yang tidak jauh berbeda dengan sampel segar, dimana permukaaannya terlihat lembut dan tidak berongga, ditandai dengan garis-garis permukaan bahan yang tidak tegas dan lubang-lubang yang hamper tidak nampak. Sampel FD secara relatif terlihat lebih porous, terbukti dengan banyaknya rongga yang terlihat di permukaan. Pori-pori diduga terbentuk akibat adanya kristal es yang terbentuk saat proses pembekuan, yang kemudian menyublim dan menyisakan struktur produk yang berongga (Wang, et al., 2018).

\section{KESIMPULAN}

\section{Kesimpulan}

Dari penelitian ini dapat disimpulkan bahwa dibandingkan dengan pengering tipe cabinet, pengering beku yang dikembangkan mampu mengeringkan petai dengan kadar air akhir yang lebih rendah serta warna petai kering yang lebih mendekati warna pada saat kondisi segar. Proses blansing terbukti mampu meningkatkan laju pengeringan petai, serta mempertahankan kandungan klorofil didalam petai, dibandingkan dengan sampel tanpa pra-perlakuan blansing.

\section{UCAPAN TERIMA KASIH}

Ucapan terima kasih pada Prof. Bambang Purwantana yang telah turut berkontribusi dalam pemikiran konsep dan perancangan mesin pengering beku. Penelitian ini dapat terlaksana berkat dukungan dana dari Universitas Gadjah Mada, melalui sebuah program bernama Rekognisi Tugas Akhir (RTA).

\section{DAFTAR REFERENSI}

Akbar, M. A., Karyadi, J. N. W., Imaniar, D. I., Mar'fuah, S., \& Hati, F. I. P. (2019). Changes of Petai during drying using freeze drying method. IOP Conference Series: Earth and Environmental Science, $355(1)$. https://doi.org/10.1088/17551315/355/1/012053

Badan Pusat Statistik. (2018). Statistik Tanaman Buah-buahan dan Sayuran Tahunan. Jakarta: Badan Pusat Statistik.

Bills, J., \& Bills, S. (2010). Dehydrating Vegetables. In Dehydrating Food (pp. 45-56). New York: Skyhorse Publishing.

Bora, D. J., Gupta, A. K., \& Khan, F. A. (2015). Comparing the Performance of 
L*A*B* and HSV Color Spaces with Respect to Color Image Segmentation. International Journal of Emerging Technology and Advanced Engineering, 5(2), 192-203. Retrieved from http://arxiv.org/abs/1506.01472

Chhikara, N., Devi, H. R., Jaglan, S., Sharma, P., Gupta, P., \& Panghal, A. (2018). Bioactive compounds, food applications and health benefits of Parkia speciosa (stinky beans): A review. Agriculture and Food Security, 7(46), 1-9. https://doi.org/10.1186/s40066-0180197-x

Eisinaite, V., Vinauskiene, R., Viskelis, P., \& Leskauskaite, D. (2016). Effects of Freeze-Dried Vegetable Products on the Technological Process and the Quality of Dry Fermented Sausages. Journal of Food Science, 81(9), C2175-C2182.

https://doi.org/10.1111/1750-

3841.13413

Esteban, R., García-Plazaola, J. I., Hernández, A., \& Fernández-Marín, B. (2018). On the recalcitrant use of Arnon's method for chlorophyll determination. New Phytologist, 217(2), 474-476. https://doi.org/10.1111/nph.14932

Guiné, R. P. F. (2018). The Drying of Foods and Its Effect on the PhysicalChemical, Sensorial and Nutritional Properties. ETP International Journal of Food Engineering, 4(2), 93-100. https://doi.org/10.18178/ijfe.4.2.93100

Hayati, S., \& Yanuwardhana, D. (2019). Jengkol \& pete ekspor unggulan Banten tujuan Uni Eropa. Retrieved December 1, 2020, from ANTARA website:

https://www.antaranews.com/video/92 2904/jengkol-pete-ekspor-unggulanbanten-tujuan-uni-eropa
Kaewsuksaeng, S., Tatmala, N., Srilaong, V., \& Pongprasert, N. (2015). Postharvest heat treatment delays chlorophyll degradation and maintains quality in Thai lime (Citrus aurantifolia Swingle cv. Paan) fruit. Postharvest Biology and Technology, 100, 1-7. https://doi.org/10.1016/j.postharvbio.2 014.09.020

Kamila, I., Karyadi, J. N. W., \& Saputro, A. D. (2019). Drying characteristics of Edamame (Glycine max. L. Merill) during freeze drying. IOP Conference Series: Earth and Environmental Science, 355(1). https://doi.org/10.1088/1755$1315 / 355 / 1 / 012048$

Kudra, T., \& Mujumdar, A. S. (2015). Special Drying Techniques and Novel Dryers. In A. S. Mujumdar (Ed.), Handbook of Industrial Drying (4th ed., pp. 433-490). Boca Raton: CRC Press Taylor \& Francis Group.

Liu, B., Wang, K., Shu, X., Liang, J., Fan, X., \& Sun, L. (2019). Changes in fruit firmness, quality traits and cell wall constituents of two highbush blueberries (Vaccinium corymbosum L.) during postharvest cold storage. Scientia Horticulturae, 246, 557-562. https://doi.org/10.1016/j.scienta.2018. 11.042

Liu, Y. H., Li, X. F., Zhu, W. X., Luo, L., Duan, X., \& Yin, Y. (2016). Drying characteristics, kinetics model and effective moisture diffusivity of vacuum far-infrared dried Rehmanniae. International Journal of Agricultural and Biological Engineering, 9(5), 208-217. https://doi.org/10.3965/j.ijabe.201609 05.2082

Mühlbauer, W., \& Müller, J. (2020). Drying Atlas - Drying Kinetics and Quality of Agricultural Products. Duxford: Elsevier 
https://doi.org/https://doi.org/10.1016/ B978-0-12-818162-1.00001-8

Nag, S., \& Dash, K. K. (2016). Mathematical modeling of thin layer drying kinetics and moisture diffusivity study of elephant apple. International Food Research Journal, 23(December), 2594-2600.

Nkwocha, A. C., Ekeke, I. C., Kamalu, C. I. O., Oghome, P. I., Osoka, E. C., \& Nkuzinna, O. C. (2018). Kinetic Modelling of Vitamin C Degradation in Selected Fruits under Market Storage Conditions. International Journal of Environment, Agriculture and Biotechnology, 3(5), 1618-1627. https://doi.org/10.22161/ijeab/3.5.7

Nollet, L. (2010). Dried Western Vegetable Products. In Y. H. Hui (Ed.), Handbook of Fruit and Vegetable Flavors (p. 1120). New Jersey: John Wiley and Sons, Inc.

Orikasa, T., Ono, N., Watanabe, T., Ando, Y., Shiina, T., \& Koide, S. (2018). Impact of blanching pretreatment on the drying rate and energy consumption during far-infrared drying of Paprika (Capsicum annuum L.). Food Quality and Safety, 2(2), 97-103. https://doi.org/10.1093/fqsafe/fyy006

Peters, K., \& Ramirez, C. (2019). Technology of Fruits and Vegetable Processing. Waltham Abbey Essex: ED-Tech Press.

Putri, M. R., \& Zuraya, N. (2019). Ekspor Pertanian Via Bandara Soekarno-Hatta Rp 1,26 T. Retrieved December 1, 2020, from Republika website: https://www.republika.co.id/berita/eko nomi/pertanian/pnkndl383/eksporpertanian-via-bandara-soekarnohattarp-126-t

Rima, P. (2018). Di Balik Baunya, Ternyata Petai Merupakan Komoditas Ekspor.
Retrieved December 3, 2020, from http://bbp2tp.litbang.pertanian.go.id/in dex.php/berita/berita-aktual/471-dibalik-baunya-ternyata-petaimerupakan-komoditas-ekspor

Roongruangsri, W., \& Bronllund, J. E. (2016). Effect of air-drying temperature on physic-chemical, powder properties and sorption characteristics of pumpkin powders. International Food Research Journal, 23(3), 962-972.

Saberian, H., Amooi, M., \& HamidiEsfahani, Z. (2014). Modeling of vacuum drying of loquat fruit. Nutrition and Food Science, 44(1), 2431. https://doi.org/10.1108/NFS-082012-0087

Sagar, V. R., Singh, S., \& Kumar P., S. (2018). Recent Development in Dehydration of Vegetable Crops. In B. Singh, S. Singh, \& T. K. Koley (Eds.), Advances in Postharvest Technologies of Vegetable Crops (pp. 381-426). Canada: Apple Academic Press, Inc.

Silva, Luis R., Peix, A., Albuquerque, C., \& Velazquez, E. (2016). Bioactive Compounds of Legumes as Health Promoters. In Luis Rodrigues da Silva \& B. M. Silva (Eds.), Natural Bioactive Compunds from Fruits and Vegetables as Health Promoters (pp. 3-26). Portugal: Bentham eBooks.

Taner, A., Oztekin, Y. B., Tekgüler, A., Sauk, H., \& Duran, H. (2018). Classification of Varieties of Grain Species by Artificial Neural Networks. Agronomy, $8(7)$. https://doi.org/10.3390/agronomy8070 123

Wang, H. O., Fu, Q. Q., Chen, S. J., Hu, Z. C., \& Xie, H. X. (2018). Effect of HotWater Blanching Pretreatment on Drying Characteristics and Product Qualities for the Novel Integrated 
Freeze-Drying of Apple Slices. Journal

of Food Quality, 2018.

https://doi.org/10.1155/2018/1347513 